\title{
PENDEKATAN TIGA TAHAP DALAM PERCEPATAN PEMBELAJARAN ILMU WARIS
}

\section{Firdaos}

Sekolah Tinggi Agama Islam (STAI) Sebelas April Sumedang, Indonesia

Email: firdaos@staisebelasapril.ac.id

\begin{abstract}
Abstrak
Penelitian ini dilatarbelakangi hasil penelitian pendahuluan tentang "Pemahaman Mahasiswa Semester dua STAI Sebelas April Sumedang Tahun Akademik 2016/2017 Terhadap Ilmu Waris". Dua indikator kesimpulan diperoleh, 1.pemahaman 37 mahasiswa terhadap ilmu waris mencapai 23,9\% kategori sedikit sekali, dan 2. Terkait kesulitan belajar ilmu waris mencapai 75,6 \% kategori sebagian besar. Penelitian ini bertujuan untuk menemukan solusi permasalahan pembelajaran materi ilmu waris yang dirasa sulit. Hal tersebut terbukti hasil penelitian pendahuluan hasilnya seperti tergambar di atas. Berdasar hal tersebut, penelitian yang dianggap sesuai dengan permasalah tersebut menggunakan penelitian tindakan kelas (PTK). Penelitian tindakan kelas ini melalui siklus 1 pertemuan satu dan pertemuan dua, dan siklus 2 pertemuan sau dan pertemuan dua dengan pola Pendekatan Tiga Tahap yaitu, tahap sau pembahasan rumus dan susunan ahli waris pihak laki-laki dan pihak perempuan, tahap dua pembahasan furudulmuqaddarah (bagian tertentu), dan tahap tiga pembahasan tata cara penghitungan pembagian waris dengan menggunakan metode deskriptif pendekatan kualitatif. Subyek penelitian 47 mahasiswa semester empat STAI Sebelas April Sumedang Tahun Akademik 2018/2019. Penelitian ini menarik kesimpulan sesuai dengan proses pembelajaran melalui Siklus 1 dan siklus 2 diperoleh rata-rata nilai 96,5\% kategori sangat tinggi.
\end{abstract}

Kata Kunci : Percepatan Pembelajaran; Ilmu Waris; Penelitian Tindakan Kelas (PTK).

\begin{abstract}
This research is motivated by the results of preliminary research on "Second Semester Student Understanding of STAI Sebelas April Sumedang Academic Year 2016/2017 Against Inheritance Science". Two conclusion indicators were obtained, 1. understanding 37 students of inheritance science reached $23.9 \%$ very little category, and 2. Related to the difficulty of learning inheritance science reached $75.6 \%$ category mostly. This study aims to find solutions to learning problems in inheritance science material that are deemed difficult. This is evident from the results of preliminary research, the results are as illustrated above. Based on this, research that is deemed appropriate to these problems uses classroom action research (PTK). This classroom action research goes through cycle 1 meeting one and meeting two, and cycle 2 meeting one and meeting two with a Three-Stage Approach pattern, namely, the first stage discussing formulas and the composition of the male and female heirs, the second stage discussing furudulmuqaddarah (section certain), and stage three discussion of the procedure for calculating the distribution of inheritance using a descriptive qualitative approach. The research subjects were 47 fourth semester students of STAI Sebelas April Sumedang, 2018/2019 Academic Year. This study draws conclusions in accordance with the learning process through cycle 1 and cycle 2, the average value of $96.5 \%$ is very high.
\end{abstract}

Keywords: Learning Acceleration; Inheritance Science; Classroom Action Research (PTK). 


\section{PENDAHULUAN}

Hasil penelitian pendahuluan yang dilakukan penulis tentang pemahaman mahasiswa semester dua STAI Sebelas April Sumedang tahun akademik 2016/2017 sebelum belajar matakuliah fiqh 3 tentang waris dan pertikahan di STAI, diperoleh kesimpulan: 1. Terkait pemahaman terhadap ilmu waris, dari delapan indikator pertanyaan, diperoleh rata-rata sebesar 23,9 \% tergolong rendah. 2. Terkait faktor kesulitan belajar ilmu waris, dari lima indikator pertanyaan, diperoleh rata-rata sebesar 75,6 \% kategori tinggi..

Hal tersebut menjadi bahan pertimbangan bagi STAI dalam hal ini dosen pengampu Mata Kuliah Fiqih 3 mencari solusi langkah-langkah/tahapan pembelajaran ilmu waris yang lebih efektif dan efisien sehingga diperoleh kecepatan tercapainya tujun pembelajaran yang diharapkan. Tujuan pembelajaran ilmu waris, mahasiswa diharapkan mampu mengidentifikasi susunan ahli waris pihak laki-lakai dan pihak perempuan, mampu menyusun proforsi pembagian, dan mampu menetapkan besaran perolehan bagi setiap ahli waris.

Berdasar latar belakang masalah di atas, penulis sebagai dosen pengampu mata kuliah Fiqih 3, melakukan proses perkuliahan materi waris dengan pendekatan 3 (tiga) langkah/tahap dalam percepatan pencapaian tujuan pembelajaran yang diharapkan interval 6 (enam) kali pertemuan dapat diketahui, sehingga pertemuan ketujuh latihan penghitungan, dan pertemuan kedelapan melakukan tes kemampuan hasil belajar sebagai alat ukur, akan diperoleh data sejauh mana ketercapaian tujuan yang telah ditetapkan. Hasilnya akan direkomendasikan kepada STAI Sebelas April Sumedang sebagai perguruan Tinggi yang mempersiapkan calon guru Pendidikan Agama Islam yang memahami tentang ilmu waris, dan menjadi bahan kebijakan setandar proses pekuliahan materi waris bagi dosen pengampu mata kuliah ilmu waris .

Tujuan umum penelitian ini adalah mendiskripsikan upaya peningkatan pemahaman mahasiswa semester empat Tahun Akademik 2018/2019 tentang materi waris melalui Pendekatan Tiga Tahap/langkah Percepatan Pembelajaran Ilmu Waris. Adapun tujuan penelitian secara khusus: a. Kemampuan mahasiswa semester empat STAI Sebelas April Sumedang Tahun Akademik 2018/2019 dalam mengidentifikasi susunan ahli waris dari pihak laki-laki dan pihak perempuan, b. Kemampuan mahasiswa semester empat STAI Sebelas April Sumedang Tahun Akademik 2018/2019 dalam menetapkan proforsi perolehan bagian bagi ahli waris, dan c. Kemampuan mahasiswa semester empat STAI Sebelas April Sumedang Tahun Akademik 2018/2019 dalam menetapkan besaran perolehan bagian setiap ahli waris. 


\section{METODE PENELITIAN}

\section{Metode}

Fokus kajian dalam penelitian ini menyangkut pemahaman dan prilaku orang dalam proses pembelajaran ilmu waris yang dianggap tepat adalah metode deskriptif pendekatan kualitatif dalam bentuk Penelitian Tindakan Kelas (PTK) karena memiliki karakteristik yang sesuai dengan permasalahan dan tujuan penelitian, yaikni untuk memperbaiki dan meningkatkan kegiatan praktik pembelajaran yang epektif dan efisien, sehingga adanya peningkatan pemahaman mahasiwa secara mudah dan cepat melalui metode /teknik pendekatan tiga tahap percepatan pembelajaran ilmu waris.

Sejalan dengan karakteristik penelitian Tindakan Dr.Suwarsih Madya, M.A. dalam bukunya Panduan Penelitian Tindakan (1994 : 12) mengatakan : "Tujuan utama penelitian jenis ini, adalah untuk mengubah perilaku penelitinya, perilaku orang lain, dan atau mengubah kerangka kerja organisasi, atau struktur lain, yang pada gilirannya menghasilkan perubahan pada perilaku peneliti-penelitinya, dan atau perilaku orang lain. Jadi penelitian tindakan lazimnya dimaksudkan untuk mengembangkan keterampilan atau pendekatan baru dan untuk memecahkan masalah dengan penerapan langsung pada ruang kelas atau ajang dunia kerja. Singkatnya, penelitian tindakan dimaksudkan untuk meningkatkan praktik tertentu dalam situasi kerja tertentu".

\section{Alur penelitian tindakan}

Empat aspek pokok dalam penelitian tindakan, yaitu penyusunan perencanaan, tindakan, observasi, dan refleksi yang dijadikan dasar alur penelitian tindakan ini. Agar memudahkan dan tidak keluar dari desain penelitian ini, penulis gambarkan melalui siklus berikut ini:

Bagan 1: Alur Penelitian Tindakan

Refleksi Awal

Catatan lapangan dan studi pendahuluan Mengidentifikasikan masalah, Kompetensi pemahaman mahasiswa semester empat STAI Sebelas April Sumedang Tahun akademik 2018/2019 terhadap materi waris masih rendah sebagai akibat dari pembelajaran yang kurang epektif . 


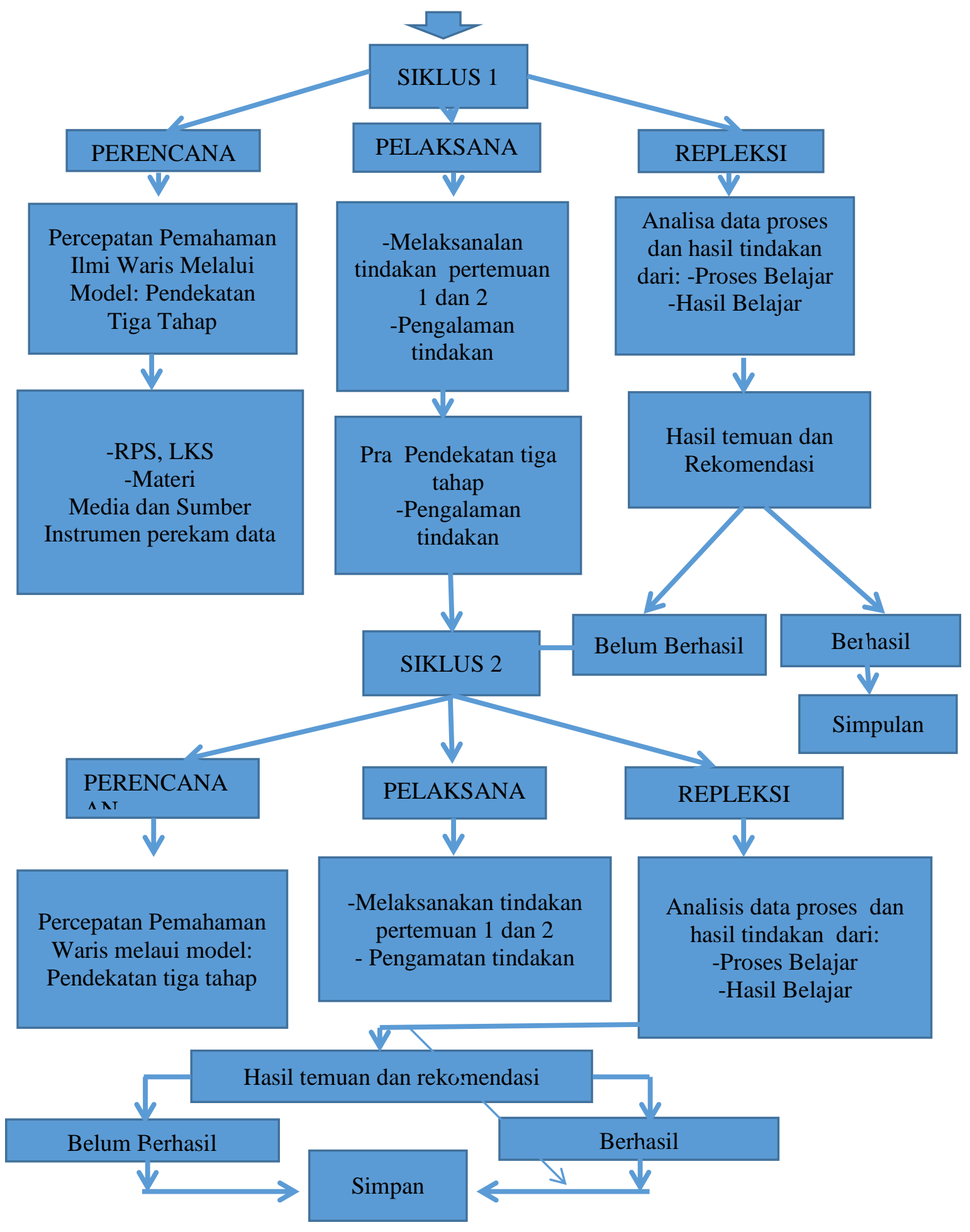




\section{Subyek dan Latar Penelitian}

Dalam penelitian ini yang menjadi subyek adalah mahasiswa STAI Sebelas April Sumedang semeter empat tahun akaemik 2018/2019 sebanyak 51 oang. Jumlah responden tidak ditentukan sebelumnya, tetapi yang lebih penting adalah dengan asumsi bahwa kontek lebih penting dari pada jumlah. Menurut Subino Hadisubroto (1988: 65) bahwa"...penelitian kualitatif tidak akan memulai dengan menghitung atau memperkirakan banyaknya populasi dan kemudian menghitung proforsi sampelnya sehingga dipandang sebagai yang lebih representatif. Sedangkan Nasution (1988: 71) menjelaskan bahwa “....penelitian unit sampel (responden) dianggap telah memadai apabila dapat diteruskan sampai dicapai taraf redundancy, ketuntasan, atau kejenuhan, artinya dengan menggunakan responden selanjutnya boleh dikatakan tidak lagi diperoleh tambahan informasi yang berarti.

Berdasarkan kutipan di atas menunjukkan bahwa besar sampel tergantung pada informasi yang diberikan responden. Apabila dianggap sudah cukup memadai, maka responden tidak perlu lagi diperbesar, sehingga dari jumlah 51 mahaiswa yang dijadikan subyek penelitian tidak mesti seluruhnya dijadikan responden, jika data yang diperlukan dianggap cukup.

Diambilnya 47 subyek penelitian mahasiswa semester empat tersebut atas dasar pertimbangan bahwa, (1) Subyek adalah mahasiswa Prodi Pendidikan Agama Islam yang dipersiapkan calon guru Pendidikan Agama Islam, dan diantara materi Pendidikan Agama Islam yaitu materi ilmu waris yang harus dipahami, (2) Materi waris termasuk pada mata kuliah Fiqih 3 yang diberikan pada semester empat, dan (3) Kompetensi mahasiswa semester empat terhadap ilmu waris masih rendah.

\section{Prosedur Kegiatan Penelitian}

Prosedur ini dilaksanakan secara bersiklus. Siklus yang dilaksanakan dalam penelitian ini adalah dua siklus, Setiap siklus dua tatap muka, melalui tahapan refleksi awal, perencanaan pelaksanaan, pemantauan dan refleksi / evaluasi. Pertemuan dari masinhg-masing siklus diagendakan pada bagan berikut ini:

Bagan.2 : Pelaksanaan Tindakan Siklus 1 dan 2 melalui keaktifan dalam Perkuliahan dengan model Pendekatan Tiga Tahap dalam Percepatan Pembelajaran Ilmu Waris

\begin{tabular}{|c|c|c|cr|}
\hline Kompetensi Dasar & $\begin{array}{c}\text { Siklus/ } \\
\text { Pertemu } \\
\text { an }\end{array}$ & Hari/Waktu & Materi Pokok \\
& $1 / 1$ & Selasa, 12 & Rumus dan Susunan Ahli \\
\hline Memahami susunan ahli & $1 / 1$ & & \\
\hline
\end{tabular}




\begin{tabular}{|c|c|c|c|}
\hline & & $\begin{array}{c}\text { Maret 2019 } \\
08.50-10.30\end{array}$ & $\begin{array}{c}\text { waris pihak laki-laki \& } \\
\text { perempuan }\end{array}$ \\
\hline $\begin{array}{c}\text { Memahami Furudul } \\
\text { Muqaddarah }\end{array}$ & $1 / 2$ & $\begin{array}{c}\text { Selasa, 19 } \\
\text { Maret }\end{array}$ & Bagian tertentu; 1/2, 1/4, 1/8, \\
& & 2019 & $1 / 3,1 / 6,2 / 3$ \\
memahami tata cara & $2 / 1$ & Selasa, 16 & Pola penghitungan waris: \\
menghitung waris & & April 2019 & normal, aul, dan rad \\
\hline Tes akhir & & $08.50-10.30$ & \\
\hline & $2 / 2$ & Selasa, 30 & Kasus menghitung waris \\
\hline
\end{tabular}

Prosedur masing-masing siklus terdiri atas (1) Refleksi awal, (2) Perencanaan tindakan, (3) Pelaksanaan tindakan dan pemantauan, dan (4) Refleksi / Evaluasi . Dari hasil refleksi / evaluasi digunakan sebagai bahan perbaikan perencanaan tindakan, pelaksanaan tindakan dan pemantapan selanjutnya sampai refleksi akhir untuk menentukan keberhasilan penelitian.

\section{HASIL DAN PEMBAHASAN}

\section{Hasil Penelitian}

Sebelum proses pembelajaran, pada awal pertemuan siklus satu pertemuan pertama, penulis melakukan prites/ tes awal dengan sebuah kasus waris, dan hasilnya sebagai bahan awal titik tolak perkuliahan mengetahui kompetensi mahasiswa dalam memahami ilmu waris. Dari hasil tes awal tersebut dari 47 mahasiswa diperoleh nilai rata-rata 8,1 . Lebih jelasnya penulis gambarkan pada bagan berikut ini :

Bagan 3 Hasil Tes Sebelum Belajar

\begin{tabular}{|l|l|c|c|c|}
\hline NO & \multicolumn{1}{|c|}{ INDIKATOR } & $\begin{array}{c}\text { JML } \\
\text { NILAI }\end{array}$ & $\begin{array}{c}\text { RATA- } \\
\text { RATA }\end{array}$ & $\begin{array}{c}\text { NILAI } \\
\text { MAX }\end{array}$ \\
\hline 1 & $\begin{array}{l}\text { Mengidentifikasi ahli waris yang berhak mendapat } \\
\text { bagian }\end{array}$ & 250 & 5,6 & 30 \\
\hline 2 & Menetapkan proforsi bagian bagi ahli waris & 109,5 & 2,4 & 30 \\
\hline
\end{tabular}




\begin{tabular}{|l|l|c|c|c|}
\hline 3 & Menetapkan besaran perolehan bagi ahli waris & 0 & 0 & 40 \\
\hline & Jumlah perolehan dan rata-rata & 359,5 & 8,1 & 100 \\
\hline
\end{tabular}

Pembelajaran pada siklus 1 dan siklus 2 , masing-masing dilaksanakan selama dua kali pertemuan. Setiap pertemuan 1 x 100 menit. Kompetensi dasar dari kedua pertemuan itu adalah pemahaman dan keterampilan mahasiswa terhadap ilmu waris meliputi: 1) Mahasiswa dapat menentukan siapa saja ahli waris yang mendapat bagian dari sebuah kasus, 2) mahasiswa mampu menetapkan proforsional perolehan bagi ahli waris dari sebuah kasus, dan 3) mahasiswa mampu menghitung berapa besaran bagian perolehan bagi ahli waris dari sebuah kasus.

Tujuan yang dikembangkan berdasarkan Kompetensi Dasar Fiqih 3, yaitu mampu memahami materi fiqih 3 tentang pertikahan dan waris. melalui model pembelajaran pendekatan tiga tahap dalam percepatan pembelajaran ilmu waris. Dari tujuan tersebut, tujuan pembelajaran secara khusus yang ingin dicapai adalah (1) mahasiswa dapat memahami susunan ahli waris dari pihak laki-laki dan pihak perempuan, (2) mahasiswa memahami tentang furudul muqaddarah (bagian-bagian tertentu), dan (3) mahasiswa mampu menyelesaikan/menghitung sebuah kasus pembagian waris secara individual pada pertemuan siklus ke 2

Materi pokok pembahasan ini, berupa materi waris terdiri dari susunan ahli waris dari pihak laki-laki dan pihak perempuan, ketetapan bagian tertentu atau furudul muqaddaroh, dan cara penghitungan pembagian waris (normal, aul, dan rad).

Pada siklus 1, pertemuan pertama mahasiswa mempelajari rumus tentang susunan ahli waris, baik dari pihak laki-laki maupun dari pihak perempuan, dan pertemuan kedua membahas tentang furudul muqaddaroh atau bagian-bagian tertentu yang sudah ditetapkan dalam alQur'an pada surat an-Nisaa ayat 11 dan 12 .

Sesuai dengan rencana dari tahapan pra pelaksanaan, saat pelaksanaan dan pasca pelaksanaan berlangsung secara efektif, tampak pada nilai hasil belajar siklus 1 pertemuan kedua oleh setiap mahasiswa dari 47 orang dengan ra-rata 75,2 tergolong tinggi. Sedangkan hasil tes awal atau pree test sebelum belajar pada siklus 1 pertemuan pertama dari 47 mahasiswa yang lebih memahami tentang rumus dan susunan ahli waris dari pihak laki-laki dan pihak perempuan serta furudul muqaddaroh memperoleh rata-rata 8,1 tergolong rendah . Ada kenaikan 67,1 dari rata-rata awal sebelum belajar ilmu waris ke siklus 1 pertemuan kedua.

Pencapaian nilai hasil belajar yang dibuktikan melalui pemahaman mahasiswa terhadap rumus dan susunan ahli waris dari pihak laki-laki dan pihak perempuan serta furudul 
muqaddaroh atau bagian tertentu dari siklus 1 pertemuan pertama dan pertemuan kedua menunjukkan peningkatan yang signifikan.

Pencapaian nilai hasil belajar dari siklus 2 pertemuan pertama dan kedua dengan memfokuskan tata cara penghitungan waris baik yang asal masalahnya sama dengan yang akan dibagikan, aul, dan rad diperoleh nilai rata-rata 96,5 kategori sangat tinggi. Ada kenaikan $\mathbf{2 1 , 3}$ dari siklus 1 ke siklus 2 .

Keberhasilan peningkatan hasi nilai rata-rata dari siklus 1 ke siklus 2 kategori sangat tinggi, hal tersebut berkat pemodelan pendekatan tiga tahap dalam percepatan pembelajaran ilmu waris mempermudah pemahaman mahasiswa semester empat STAI Sebelas April Sumedang Tahun Akademik 20182019 terhadap ilmu waris. Berikut hasil peningkatan pencapaian hasil belajar:

Bagan 4 Peningkatan Pencapaian Hasil Belajar

\begin{tabular}{|c|c|c|c|c|c|c|}
\hline \multirow[t]{2}{*}{ Pokok Bahasan } & \multicolumn{3}{|c|}{$\begin{array}{c}\text { Siklus } \\
1\end{array}$} & \multicolumn{3}{|c|}{$\begin{array}{c}\text { Siklus } \\
2\end{array}$} \\
\hline & $\begin{array}{c}\text { Jml } \\
\text { Nilai }\end{array}$ & $\begin{array}{l}\text { Rata- } \\
\text { Rata }\end{array}$ & $\begin{array}{l}\text { Nilai } \\
\text { Max }\end{array}$ & $\begin{array}{c}\text { Jml } \\
\text { Nilai }\end{array}$ & $\begin{array}{l}\text { Rata- } \\
\text { rata }\end{array}$ & $\begin{array}{r}\text { Nilai } \\
\text { max }\end{array}$ \\
\hline $\begin{array}{l}\text { Mengidentifikasi susunan ahli waris } \\
\text { pihak laki-laki dan perempuan }\end{array}$ & 1086 & 24,6 & 30 & 1315 & 29.8 & 30 \\
\hline $\begin{array}{c}\text { Menetapkan proforsi bagian perolehan } \\
\text { bagi ahli waris }\end{array}$ & 1046 & 23,7 & 30 & 1310 & 29 & 30 \\
\hline $\begin{array}{c}\text { Menetapkan besaran perolehan bagi ahli } \\
\text { waris }\end{array}$ & 1184 & 26,9 & 40 & 1662 & 37,7 & 40 \\
\hline J u m l a h & 3314 & 75,2 & 100 & 4287 & $\begin{array}{c}96,5 \\
\text { (sangat } \\
\text { Tinggi) }\end{array}$ & 100 \\
\hline
\end{tabular}

Hasil evaluasi terakhir dari pembelajaran pada siklus 2 pertemuan kedua menunjukkan adanya kenaikan mulai dari siklus 1 pertemuan kesatu sampai siklus 2 pertemuan kedua mencapai rata-rata prosentase melalui model pembelajaran dengan pendekatan tiga tahap dalam percepatan pembelajaran ilmu waris sebesar, 96,5 \% kategori sangat tinggi. 


\section{Pembahasan}

Pelaksanaan pembelajaran melalui tahapan yang telah ditetapkan menunjukkan mampu mengaktifkan mahasiswa terlihat secara aktif dalam tahap proses pembelajaran yang mempokuskan pada (1) pemahaman mahasiswa terhadap susunan ahli waris dari pihak lakilaki dan pihak perempuan, (2) pemahaman mahasiswa terhadap furudul muqaddaroh (bagian tertentu), dan (3) pemahaman serta keterampilan mahasiswa dalam menghitung pembagian harta waris melalui pendekatan tiga tahap dalam percepatan pembelajaran ilmu waris.

Pada siklus 1 pertemuan pertama mahasiswa mempelajari rumus tentang memahami susunan ahli waris. Dosen bersama mahasiswa mengamati rumus melalui gambar untuk memahami dan hafal rumus tersebut, bahwa susunan ahli waris selalu berpusat atau kembali kepada si mayat. Ahli waris terdiri dari: (1) furuul mayit (cabang dari mayit) meliputi anak, cucu si mayit, (2) Ushulul mayit (asal si mayit) meliputi bapak, ibu, kakek, nenek, dan paman serta anaknya, dan (3) Hawasi (saudara si mayit) meliputi saudara sekandung dengan mayit beserta anaknya, saudara sebapak simayit beserta anaknya, dan saudara se ibu dengan si mayit.

Berikut penulis gambarkan melalui bagan tentang rumus memahami susunan ahli waris dan bagan susunan ahli waris dari pihak laki-laki dan pihak perempuan.

Bagan 5 Rumus Susunan Ahli Waris

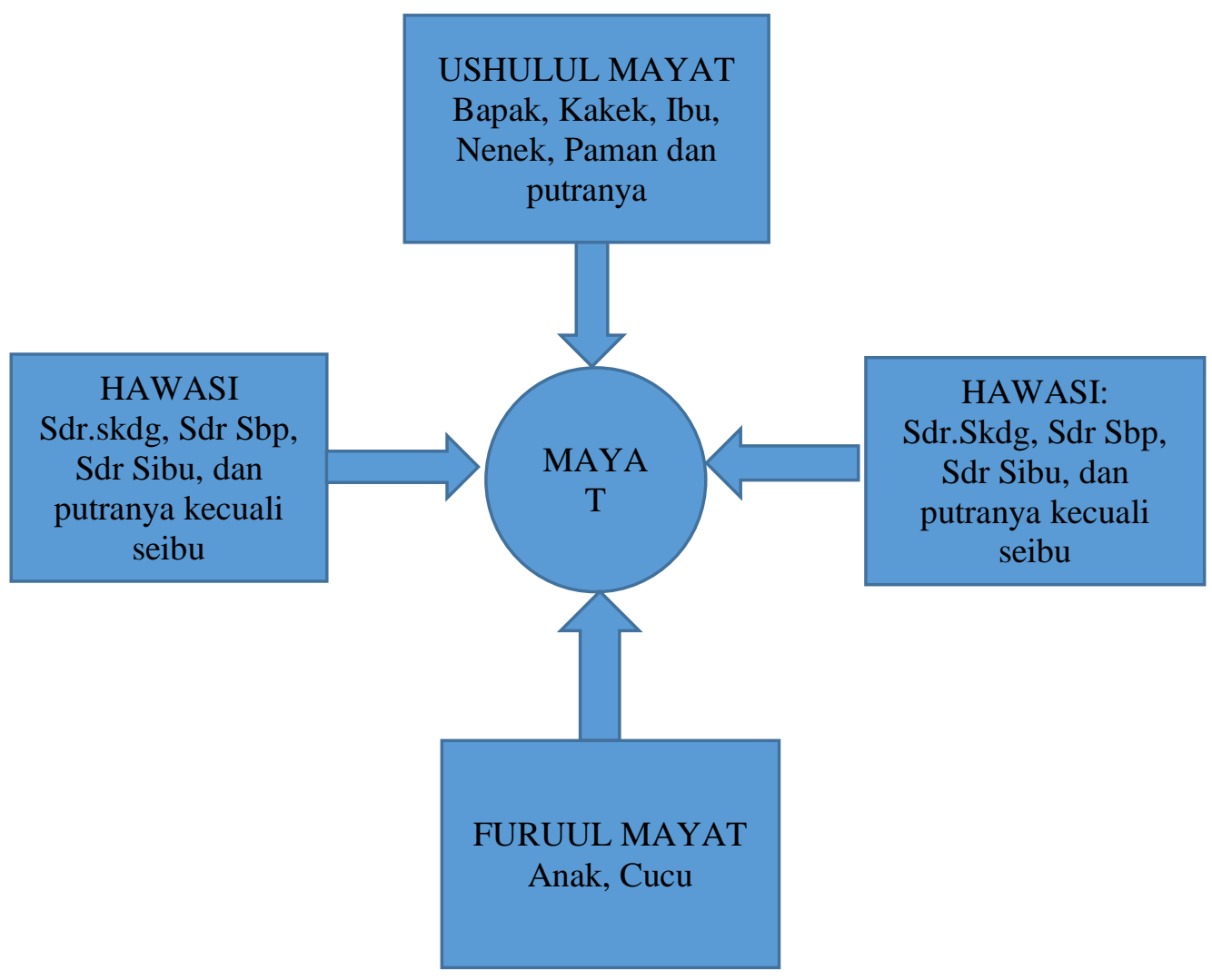


Dosen bersama mahasiswa mengulang-ulang tentang rumus ahli waris serta susunan ahli waris baik dari pihak laki-laki maupun ahli waris dari pihak perempuan. Dengan motode dril ini mahasiswa terbantu atas pemahaman rumus dan susunan ahli waris baik dari pihak lakilaki maupun dari pihak perempuan. Hal ini ketika mahasiswa faham tentang rumus susunan ahli waris baik dari pihak laki-laki maupun perempuan akan mempermudah pemahaman pada siklus 1 pertemuan kedua tentang furudul muqaddaroh atau bagian tertentu dengan pola nasabiah/ keturunan, pertikahan, dan perwalian sesuai bagan susuna ahli waris dari pihak lakilaki dan pihak perempuan yang sudah disiapkan dosen. Ahli waris pihak laki-laki ada 15 meliputi anak laki-laki si mayit, cucu laki-laki dari anak laki-laki si mayit, bapak si mayit, kakek si mayit dari bapak,saudara laki-laki kandung dan putranya, saudara laki-laki sebapak dan putranya, saudara laki-laki seibu dengan mayit, paman se kandung dengan bapak si masit beserta putranya, paman sebapak dengan bapak simayit beserta putranya, suami, dan mu”tiq, sedangkan ahli waris dari pihak perempuan ada 10 meliputi anak perempuan, cucu perempuan dari anak laki-laki, ibu, nenek dari ibu, nenek dari bapak, saudara perempuan sekandung, saudara perempuan se bapak, saudara perempuan seibu, isteri, dan mu'tiqoh.

Bagan 6. Susunan ahli waris pihak laki-laki 15 orang :

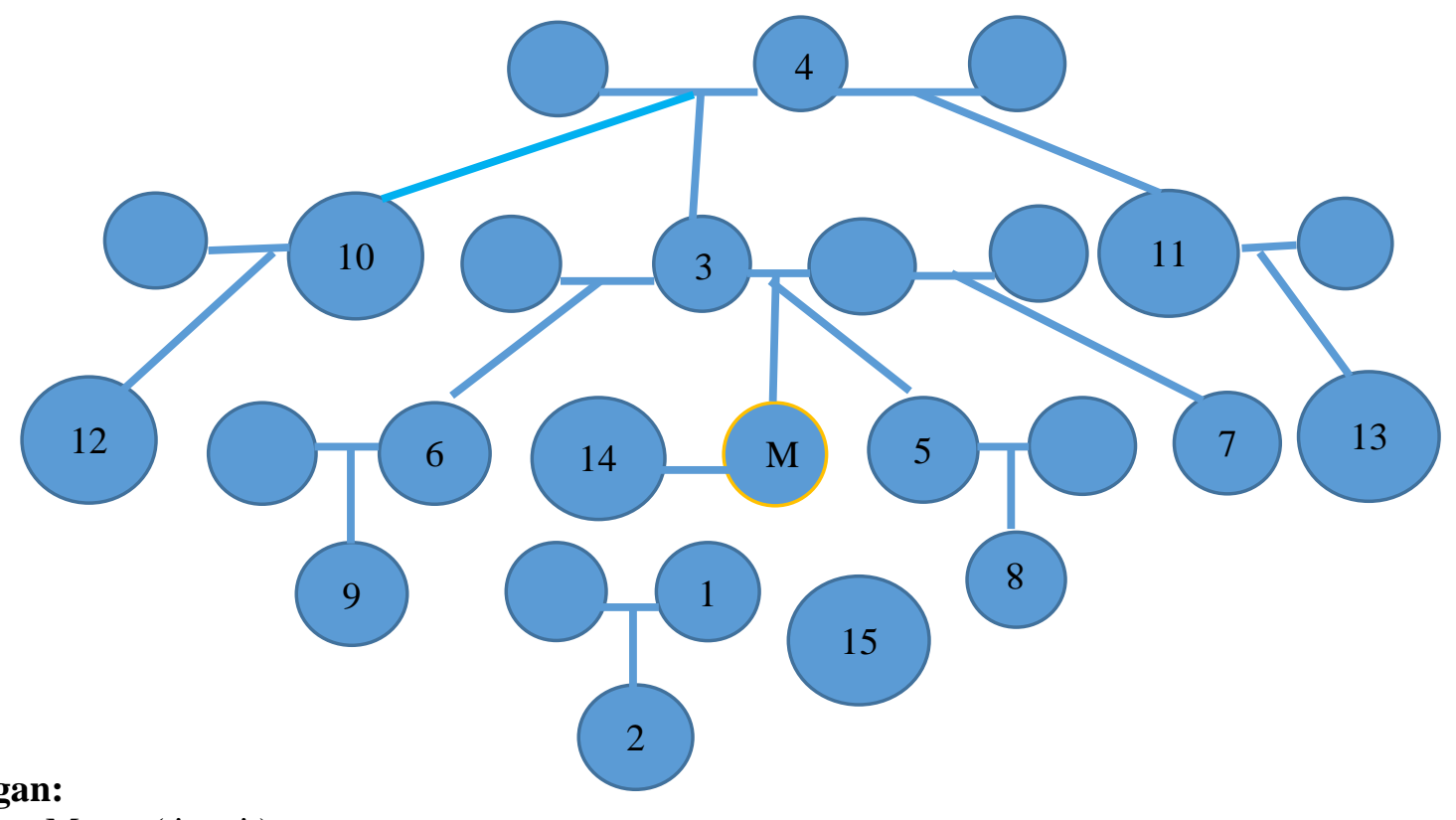

\section{Keterangan:}

$\mathrm{M} \quad=$ Mayat ( isteri )

No 1 s.d 13 = Ahli waris nasabiyah (keturunan)

No 14 = Suami ( sebab perkawinan ).

No $15 \mathrm{Mu}$ 'tik yang memerdekakan si mayat 
Bagan 7. Susunan Ahli Waris pihak Perempuan ada 10 orang

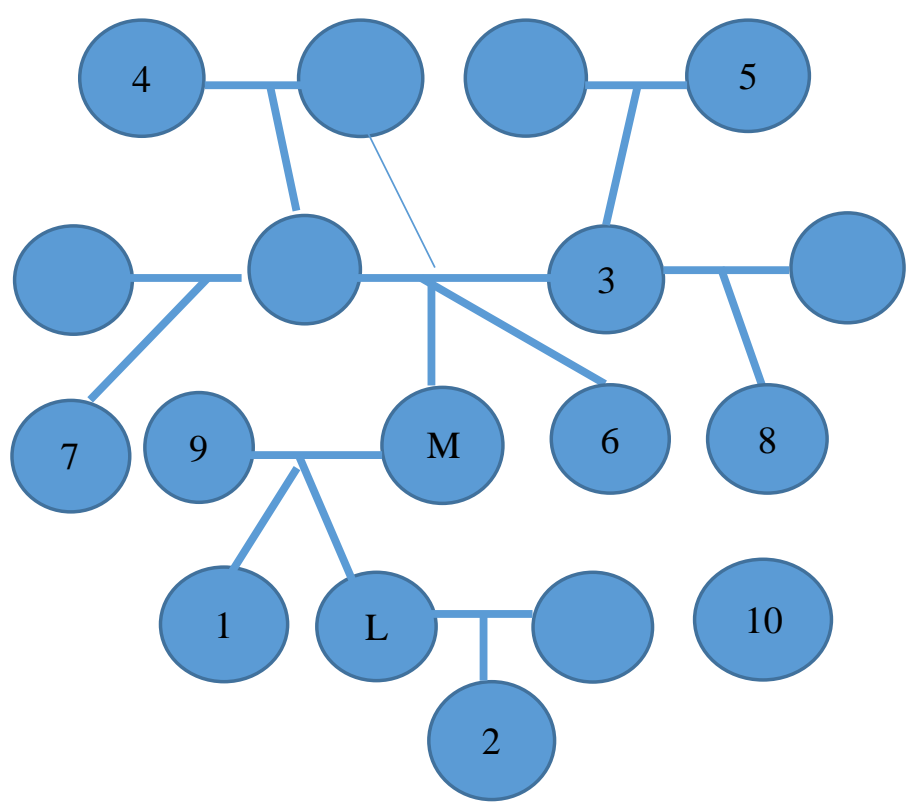

Dari pembelajaran materi pokok susunan ahli waris dapat sekaligus menjelaskan tentang sebab-sebab menjadi ahli waris yaitu sebab nasabiah (keturunan), perkawinan, dan perwalian. Begitu juga dapat dijelaskan sebaliknya sebab-sebab tidak mendapat warisan, yaitu sebab membunuh, beda agama, dan murtad.

Pada siklus 1 pertemuan kedua, mahasiswa memahami dan trampil memetakan proforsi perolehan sesuai dengan furudul muqaddaroh (bagian tertentu) dengan pola pendekatan nasabiah/keturunan melalui teknik jenis kelamin dan posisi nasab, perkawinan, dan perwalian. Di dalam pembahasan furudul muqaddaro, juga dibahas tentang asobah, hijab, dzawil furud, dzawil arham, dan wasiat.

Ada tiga cara dalam penghitungan pembagian harta waris, yaitu a. Cara normal, yaitu jumlah yang akan dibagikan sama besarnya dengan jumlah asal masalah, b. Cara rad yaitu jumlah yang akan dibagikan lebih sedikit dari pada jumlah asal masalah, dan d. Cara aul yaitu jumlah yang akan dibagikan lebih besar dari pada jumlah asal masalah.

Pada saat pembelajaran tentang tata cara penghitungan pembagian waris, pada siklus 2 pertemuan kesatu diawali dengan penjelasan hal-hal yang harus diperhatikan sebelum pembagian harta waris yaitu hutang si mayit, zakat, wasiat, dan biaya pengurusan jenazah. Pola penghitungan dengan tiga cara, yaitu yang normal artinya jumlah yang akan dibagikan sama dengan asal masalah /KPT, aul, dan rad. Setelah seluruh harta dinilaikan dengan uang diambil 4 hal yang harus diperhatikan, sisanya diambil dulu bawaan masing-masing pada saat awal pertikahan dan sisanya dibagi dua untuk suami dan isteri, yang dibagikan adalah hak yang meninggal dari bagian masing-masing ditambah bawaan pada saat awal pertikahan. Jika awal 
pertikahan tidak dapat diketahui, harta keseluruhan setelah diambil empat macam di atas langsung dibagi dua.

Pada siklus 2 pertemuan kedua, mahasiswa melakukan tes uji kompetensi menghitung pembagian harta waris melalui sebuah kasus. Hasilnya dijadikan sebuah kesimpulan hasil penelitian tindakan

Model pembelajaran dengan pola pendekatan tiga tahap dapat mengurangi kesulitan mahasiswa dalam mempelajari ilmu waris, dan menjadi solusi materi waris yang cukup banyak dapat disederhanakan dengan tidak mengurangi materi waris secara keseluruhan.

\section{KESIMPULAN}

Sesuai dengan rumussan masalah dan tujuan penelitian, secara umum dapat disimpulkan bahwa melalui model pembelajaran pendekatan tiga tahap dalam percepatan pembelajaran ilmu waris mulai dai siklus 1 sampai siklus 2, pemahaman dan keterampilan mahasiswa semester empat STAI Sebelas April Sumedang tahun akademik 2018/2019 terhadap materi ilmu waris meningkat. Secara khusus dapat disimpulkan bahwa peningkatan hasil prestasi belajar mahasiswa tampak pada pemahaman dan keterampilan menghitung sebuah kasus pembagian waris dengan hasil nilai rata-rata 96,5 sangat tinggi. Dengan model pendekatan tiga tahap dalam percepatan pembelajaran ilmu waris cukup efektif dan efisien dilakukan sebagai solusi pembelajaran tentang materi ilmu waris yang cukup banyak .

\section{REFERENSI}

Bogdan RC \& Biklen. SK (1982), Qualitative Research for Education An Introduction to Theory and Methods, Massachussets: Allyn and Bacon, Inc.

Bogdan Robert dan Tylor. J.Steven, (1993), Dasar-dasar Penelitian kualitatif (terjemahan A.Khosin Apandi, Surabaya, Usaha Nasional.

De Porter,B.Hernacki,M, (2000), Quantum Learning, Bandung, Penerbit Kaifa

Instruksi Presiden RI, (197 ), Kompilasi Hukum Islam, Jakarta

Langgulung, Hasan, (1985), Beberapa Pemikiran Tentang Pendidikan Islam,Bandung,PT.Ma'arif.

Lexy J,Moleong, (1989), Metodologi Penelitian Kualitatif, Bandung, PT. Remaja Rosdakarya. 
Mughniyah Muhammad Jawad, (2001), Fiqih Lima Mazhab,Jakarta, PT.Lentera Basritama.

Nashar, (2004), Peranan Motivasi Kemampuan Awal dalam Kegiatan Pembelajaran, Jakarta, Delia Press.

Nasution S, (1992), Metode Penelitian Naturalistik Kualitatif, Bandung, Tarsiyo.

Noeng Muhadjir, (1990), Metode Penelitian Kualitatif, Yogyakarta, Raka Sarasih.

PP.RI No.19, (2005), Standar Nasional Pendidikan, Jakarta, Han's Print.

Rahman Fatchur, (1987), Ilmu Waris, Bandung, PT.Ma'arif.

Ramayulis, (2010), Metodologi Pendidikan Agama Islam, Jakarta, Kalam Mulia Pendidikan

Ruseffendi ET. (2005), Dasar-dasar Penelitian Pendidikan \& Bidang non-Eksakta Lainnya, Bandung, Tarsito.

Sabiq Sayyid, (1993), Fikih Sunnah, alih bahasa Mudzakir AS., Bandung, PT.Al-Ma’arif.

Suparman, Ali Sudarman, (1981), Metode Penelitian Praktis, FE.UGM, Yogyakarta.

Suprijono Agus, (2009), Cooperative Learning Teori \& Aplikasi PAIKEM, Yogyakarta, Pustaka Pelajar.

Tafsir Ahmad, (1992), Metodik Khusus Pendidikan Agama Islam, Bandung, PT.Rosdakarya. 